\title{
Smoking in South Africa: the health and economic impact
}

\author{
Derek Yach, Di McIntyre, Yusuf Saloojee
}

\begin{abstract}
Objective-To describe the health and economic impact of tobacco in South Africa and to indicate current prevention activities.
\end{abstract}

Methods - Routinely available mortality statistics, hospital discharge data, and prevalence data from the private and public sectors were collated and analysed. Results - In 1988 deaths from smokingrelated diseases in South Africa accounted for $33.7 \%$ of white, $25.8 \%$ of Asian, $16.6 \%$ of coloured (mixed race), and $5.4 \%$ of African deaths. The percentage of all potential years of life lost (35 to 64 years) owing to deaths from smoking-related diseases between 1968 and 1988 declined among white and Asian men but increased among other groups.

The overall smoking rate in 1989-90 in people over 16 years of age was $31 \%$. Smoking rates among African and coloured men were particularly high; rates among African and Asian women were particularly low; rates for all races were lowest among those with a university education. When the 1976 smoking rates were applied to the 1990 base population, there were 320000 more African smokers, 80000 more coloured smokers, 40000 more Asian smokers, and 270000 fewer white smokers. Increases were related to the unopposed impact of aggressive tobacco company marketing among susceptible groups. Advertisers targeted cinemas, billboards, and the radio. The total economic cost of smoking-related diseases was estimated to be between 1390 billion and 2453 billion rands in 1988 ( $\$ 1$ is about 2.5 rands).

Conclusion - As South Africa undergoes further sociopolitical change, comprehensive tobacco prevention programmes are needed to ensure that gains made in reducing infectious diseases are not eclipsed by the costs of increasing smoking-related disease.

(Tobacco Control 1992; 1: 272-80)

\section{Introduction}

It is believed that tobacco was introduced into Africa in the fourteenth century, when the Turks introduced it to Egypt. ${ }^{1}$ In about 1560 the Portuguese and Spaniards brought it down the east coast towards East Africa, and from there its cultivation spread through central and western Africa. Later evidence showed that the Portuguese brought it directly to the Cape during the 1650 s. $^{2}$ The first Dutch Governor at the Cape, Van Riebeeck (himself a barber surgeon), probably brought it to Cape Town in 1652. Tobacco farming then rapidly became established in South Africa and tobacco was for many years often used as a form of currency among the early settlers. The largest South Africa cigarette maker, Rembrandt, manufactured its first cigarette in $1948 .^{3}$

In 1978 Muller warned that cigarettes were being pushed by high pressure marketing to the most remote corners of the world and that tobacco-related disease would constitute "tomorrow's epidemic." ${ }^{4}$ For example, in 1988 alone, while consumption of cigarettes fell by $1 \%$ in the developed countries, it rose by $2.3 \%$ in the developing world. ${ }^{5}$ As a result of these increases in tobacco consumption, disease, disability, and death from tobacco will increase in the future. It is estimated that annual deaths from cigarettes will quadruple globally from the current 2.5 million to about 10 million by 2030 , and the bulk of these deaths will be in developing countries. ${ }^{6}$

The aim of this paper is to present the latest South African data on the health and economic impacts of tobacco use; trends in tobacco consumption; and the status of legislation, education, and non-governmental organisations in creating a social environment in which non-smoking is seen as the norm.

South Africa combines the worst health consequences of industrialisation and poverty - a high incidence of heart disease and cancer mainly among the white (of European origin) and Asian (mainly from the Indian subcontinent) populations and endemic patterns of preventable infectious and nutritional diseases among the African (indigenous black) and coloured (mixed race) populations. Apartheid policy combined with urbanisation has resulted in health and other social services being inequitably distributed. This has been extensively reviewed and shown to have resulted in health status and health-related behaviour being strongly related to race. ${ }^{7-9} \mathrm{It}$ is for that reason that data are presented here by race - still a stronger determinant of status than social class.

\section{Extent of tobacco use}

Data on the prevalence of smoking in South Africa are derived mainly from marketing companies. The major survey group (AMPS) 
has been active in South Africa for nearly 20 years, making time trends possible. The national surveys have used as a basis for their sampling frame the national censuses of 1970 , 1980, and 1985. Adjustments for undercounting of the African population are made. Stratified random samples of households are obtained. A total of 1500 respondents per population group are selected. In all cases interviews are carried out in the home of respondents. Smokers are defined as having smoked at least one cigarette a day for three months and ex-smokers as having not smoked for at least three months after having previously met the criterion for being a smoker. In addition to these national surveys, local or regional surveys are carried out on an ad hoc basis, mainly by the Medical Research Council. Both sources are used here.

\section{CURRENT SMOKING PREVALENCE IN SOUTH} AFRICA

The overall smoking rate in $1989-90$ for adults (over 16 years of age) was $31 \%$. This translates into 6.85 million current adult South African smokers.

Table 1 and figure 1 provide the latest information with regard to smoking prevalence by race, sex, age, and education level in South Africa. Smoking prevalence among African and coloured men is particularly high; rates among African and Asian women are particularly low; and rates for all races are lowest among those who have completed a university education.

CHANGES IN SMOKING PREVALENCE SINCE 1976 Comparisons between 1976 and 1990 indicate that if the smoking prevalence in 1976 are applied to the 1900 base population there are 320000 more African smokers, 80000 more coloured smokers, 40000 more Asian smokers and, importantly, 270000 fewer white smokers. The increases are related to increased targeting of groups vulnerable to the unopposed impact of aggressive tobacco company marketing. ${ }^{10}$

Among white people, the percentage decline over the past 15 years has been similar in men and women (roughly $7 \%$ ) but most obvious among those aged 16-24 and among those with a university education. Increases in the other groups are particularly large in the cohorts

Table 1 Smoking prevalence (percentage) in South Africa by race, 1989-90

2

\begin{tabular}{|c|c|c|c|c|}
\hline & White & African & Coloured & Asian \\
\hline Total & $33 \cdot 7$ & $28 \cdot 4$ & $48 \cdot 7$ & $27 \cdot 6$ \\
\hline Age (years): & & & & \\
\hline $16-24$ & $30 \cdot 5$ & $23 \cdot 5$ & $39 \cdot 7$ & $19 \cdot 0$ \\
\hline $25-34$ & $41 \cdot 0$ & $37 \cdot 2$ & $60 \cdot 0$ & $30 \cdot 5$ \\
\hline $35-49$ & $40 \cdot 1$ & 32.9 & $56 \cdot 9$ & $35 \cdot 6$ \\
\hline$\geqslant 50$ & $24 \cdot 5$ & 17.9 & $35 \cdot 8$ & $24 \cdot 2$ \\
\hline Educational level: & & & & \\
\hline Completed 6 years & $29 \cdot 7$ & $35 \cdot 4$ & $53 \cdot 5$ & $29 \cdot 2$ \\
\hline Completed 12 years & $35 \cdot 6$ & $30 \cdot 6$ & $45 \cdot 6$ & $26 \cdot 6$ \\
\hline Completed university & $20 \cdot 4$ & $21 \cdot 4$ & $20 \cdot 6$ & $\mathrm{n} / \mathrm{a}^{\star}$ \\
\hline $\begin{array}{l}\% \text { total adult population } \\
(\mathrm{n}=22 \cdot 1 \text { million })\end{array}$ & $16 \cdot 7$ & $71 \cdot 9$ & $8 \cdot 7$ & $2 \cdot 7$ \\
\hline
\end{tabular}

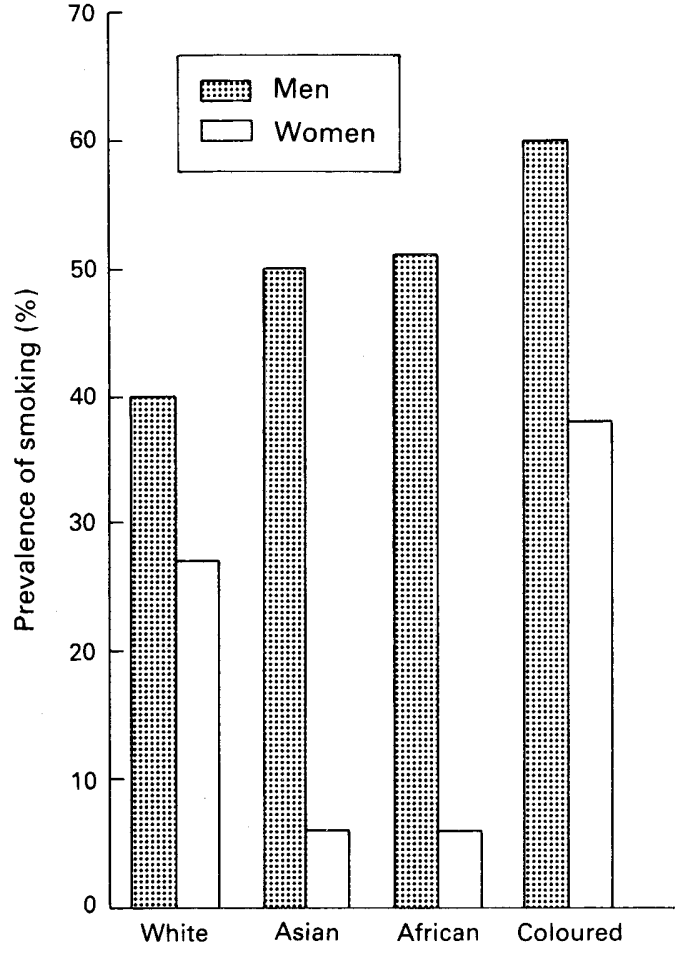

Figure 1 Prevalence of smoking in South African adults by race, 1989-90

followed from 1976 to 1989 , who were 16 to 24 years old in 1976. Importantly, the proportion of women who smoke remains low and has not changed among Africans from 1976 to 1989-90. This suggests that this group remains resistant to smoking initiation despite the onset of marketing, and they should be encouraged to act as role models to prevent further increases in other groups. (The recently created International Network of Women Against Tobacco could help in this regard.)

Table 2 provides further information about smoking rates in representative samples selected in community-based studies of risk factors for coronary heart disease. ${ }^{11-15}$ These confirm the national picture.

\section{SMOKING AMONG ADOLESCENTS}

Two crucial groups to investigate are adolescents and children. Recently conducted studies of 673 higher primary school African pupils in the Western Cape region of South Africa showed that $27.3 \%$ of boys (mean age 14.3 years) and only $0.8 \%$ of girls smoked. ${ }^{16.17}$ The median age of onset of smoking for boys was 14 years, with smoking prevalence rates rising from $6.3 \%$ in those under 12 to $45 \%$ in those aged 16 and over. Peer pressure was a significant determinant of smoking among boys. ${ }^{7}$ The most commonly consumed brands were those most aggressively marketed in the region.

In table 3 smoking prevalence is indicated by language, sex, and age. This study for the first time used an entire metropolitan area (independent of race) as the sampling frame. Sex differences, favouring higher rates among boys, increase with age. The prevalence in young Xhosa speaking girls is higher than that in older girls. This could indicate a change in a group who previously did not smoke. 
Table 2 Smoking prevalence recorded in coronary risk factor community surveys in South Africa ${ }^{11-15}$

\begin{tabular}{|c|c|c|c|c|c|c|}
\hline \multirow[b]{3}{*}{ First author } & \multirow{3}{*}{$\begin{array}{c}\text { Race } \\
\text { (urban/rural) }\end{array}$} & \multirow{3}{*}{$\begin{array}{l}\text { Age group } \\
\text { (years) }\end{array}$} & \multicolumn{4}{|c|}{ Cigarette consumption per day } \\
\hline & & & \multicolumn{2}{|c|}{ Men } & \multicolumn{2}{|c|}{ Women } \\
\hline & & & $\geqslant 1$ & $\geqslant 10$ & $\geqslant 1$ & $\geqslant 10$ \\
\hline Seedat ${ }^{14}$ & Asian (urban) & $15-70$ & $56 \cdot 4$ & $41 \cdot 9$ & $12 \cdot 4$ & $5 \cdot 7$ \\
\hline Steyn ${ }^{13}$ & African (urban) & $15-64$ & $52 \cdot 0$ & $24 \cdot 7$ & $8 \cdot 4$ & $1 \cdot 6$ \\
\hline Steyn $^{12}$ & Coloured (urban) & $15-64$ & $59 \cdot 8$ & $39 \cdot 8$ & $41 \cdot 4$ & $25 \cdot 0$ \\
\hline Steenkamp" & White (rural) & $15-64$ & $48 \cdot 1$ & $40 \cdot 1$ & 17.9 & $12 \cdot 9$ \\
\hline Mollentze (unpublished) & African (rural) & $24-70$ & $32 \cdot 8$ & 14.9 & $4 \cdot 2$ & 0.5 \\
\hline
\end{tabular}

Table 3 Percentage of students who smoke at least one cigarette per day in the western Cape region of South Africa (1990) by language, sex, and age $(n=7340)^{\star}$

\begin{tabular}{|c|c|c|c|c|c|c|}
\hline \multirow[b]{3}{*}{ Age (years) } & \multicolumn{6}{|c|}{ Language } \\
\hline & \multicolumn{2}{|c|}{ English } & \multicolumn{2}{|c|}{ Afrikaans } & \multicolumn{2}{|c|}{ Xhosa } \\
\hline & Male & Female & Male & Female & Male & Female \\
\hline $\begin{array}{c}\leqslant 14 \\
15-17 \\
\geqslant 18\end{array}$ & $\begin{array}{l}10 \cdot 2 \\
29 \cdot 5 \\
35 \cdot 0\end{array}$ & $\begin{array}{r}9 \cdot 7 \\
22 \cdot 7 \\
24 \cdot 8\end{array}$ & $\begin{array}{r}8 \cdot 7 \\
22 \cdot 6 \\
26 \cdot 4\end{array}$ & $\begin{array}{r}8 \cdot 6 \\
13 \cdot 4 \\
27 \cdot 0\end{array}$ & $\begin{array}{r}9 \cdot 6 \\
17 \cdot 4 \\
25 \cdot 1\end{array}$ & $\begin{array}{l}5 \cdot 0 \\
3.0 \\
0.9\end{array}$ \\
\hline
\end{tabular}
* Data provided by Alan Flisher, Psychiatry Department, Uni-
versity of Cape Town, 1991 .

\section{Impact of tobacco use on death and disease}

Mortality statistics are analysed by the Medical Research Council using computer tapes of annual deaths made available directly from Central Statistical Services.

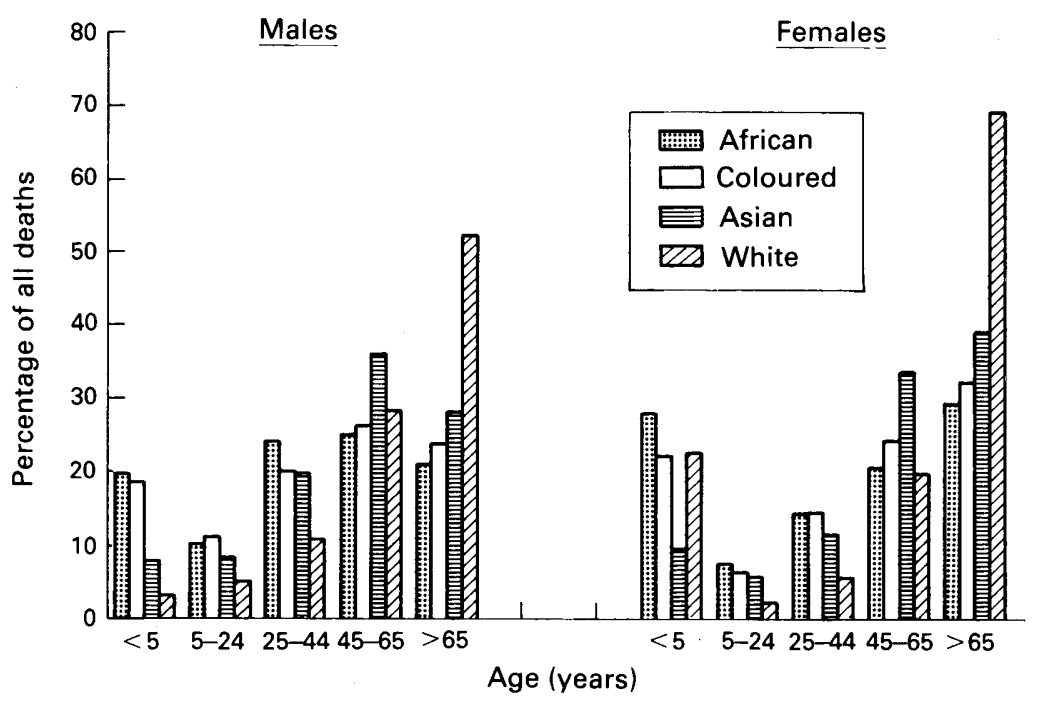

Figure 2 Distribution of deaths by race and age in South Africa, 1984-6

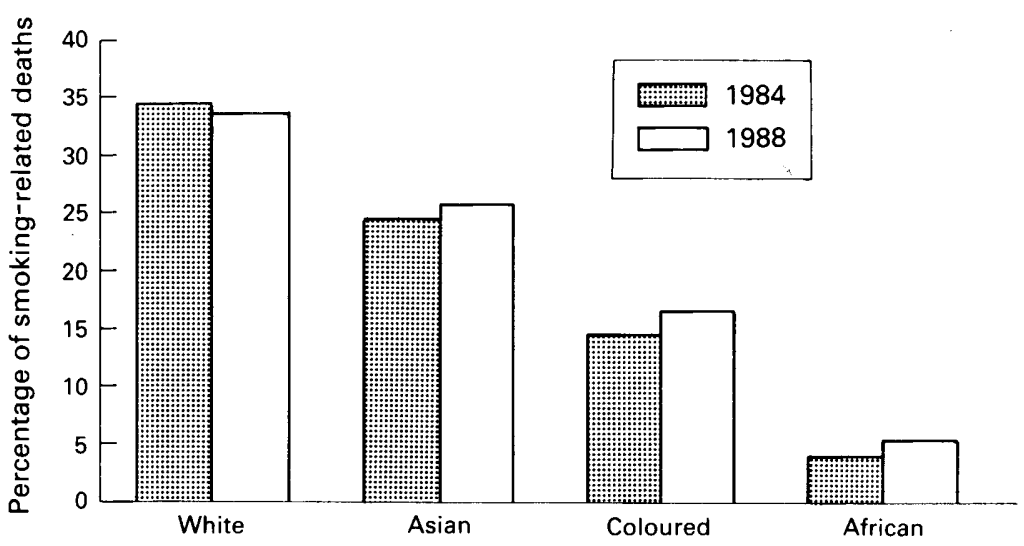

Figure 3 Deaths from smoking-related diseases as a percentage of all deaths in South Africa by race in 1984 and 1988
EPIDEMIOLOGICAL AND DEMOGRAPHIC

TRANSITION IN SOUTH AFRICA

To contextualise the impact of tobacco-related deaths it is first necessary to describe the underlying demographic and epidemiological changes in the country. These are strongly related to race, mainly because of the forced relation between socioeconomic class and race induced by apartheid policies. With the demise of apartheid, race and social class may well diverge over the next generation, but the legacy of apartheid will remain for some time. For that reason statistics are presented here by race.

Figure 2 shows the distribution of deaths by age and the appreciable differences both by sex and by race. The crucial differences relate to the high proportion of mainly preventable infectious disease deaths that still afflict African and coloured children, while among Asian and white people deaths at older ages predominate. For example, estimated infant mortality rates in the mid-1980s were 12.3 deaths per 1000 live births in white people, 17.9 in Asians, 51.9 in coloured people, and in excess of 90 in Africans, ${ }^{18}$ with gastroenteritis accounting for a quarter of the deaths among coloured and African children under 5 years.

Of particular importance to this report is the high proportion of deaths from 45 years onwards. Analyses of trends from 1968 to 1986 show that there have not been major declines in the proportion of deaths between 45 and 64 years of age. The bulk of deaths in these age groups are attributable to smoking-related diseases. ${ }^{19}$

DEATHS FROM SMOKING-RELATED DISEASES

In this review smoking-related diseases include ischaemic heart disease (ICD 410-414), lung cancer (ICD 162), respiratory heart disease (ICD 415-417), chronic obstructive airways disease (ICD 490-496), and aortic aneurysm (ICD 441), where ICD is the ninth revision of the International Classification of Diseases (1975).

Figure 3 compares deaths from smokingrelated diseases in South Africa between 1984 and 1988 by race. Important differences over time emerge. Though the contribution to all deaths has declined among white subjects, the absolute number of deaths in this group grows. In all other races the proportion of deaths from smoking-related diseases has increased, and in the case of Africans and coloured people this translates into substantial increases in the absolute number of deaths as a result of 


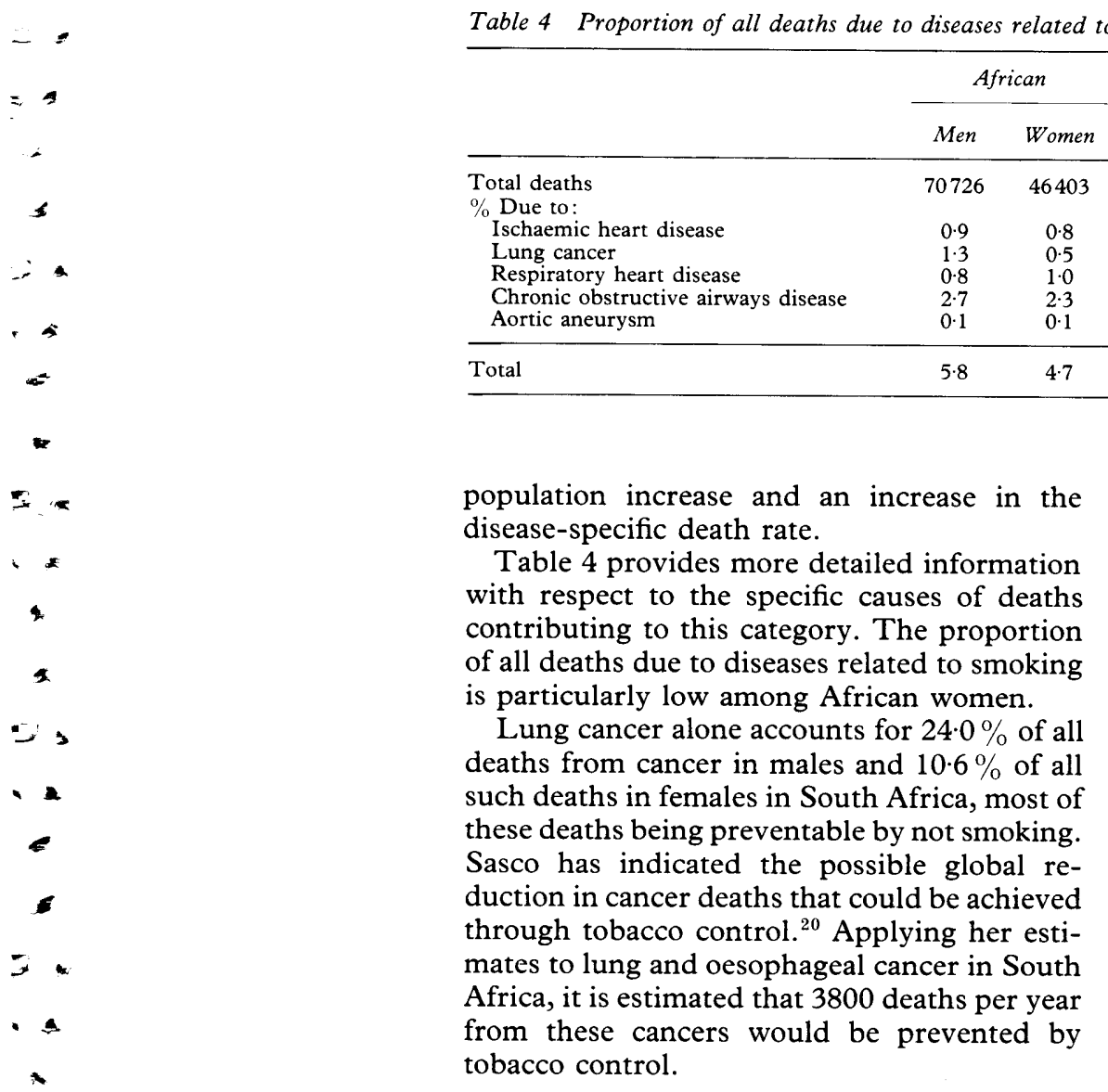

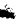

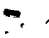

4

$\$$

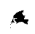

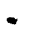

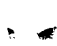

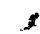

3

$\therefore$
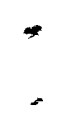

2. 2

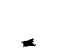

$+$

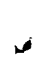

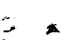

poulation increase and an increase in the isease-specific death rate.

Table 4 provides more detailed information contributing to this category. The proportion of all deaths due to diseases related to smoking is particularly low among African women.

Lung cancer alone accounts for $24.0 \%$ of all eaths from cancer in males and $10.6 \%$ of all these deaths being preventable by not smoking. Sasco has indicated the possible global reduction in cancer deaths that could be achieved through tobacco control. ${ }^{20}$ Applying her esties to lung and oesophageal cancer in South from these cancers would be prevented by tobacco control.

\section{YEARS OF POTENTIAL LIFE LOST OWING TO} SMOKING-RELATED DISEASES

Figure 4 examines the mortality data in a different way. The percentage of all years of potential life lost between 35 and 64 years because of smoking-related diseases in South Africa are compared from 1968 to 1988. (Data for Africans were not available in 1968.) There have been substantial declines in the proportion of deaths due to smoking-related diseases among white and Asian men with less impressive declines among white women. In the other groups there have been steady increases in the proportion over time. As the proportion of childhood deaths declines and the population ages, there will be noticeable increases in smoking-related death and disease.

Deaths from smoking-related diseases

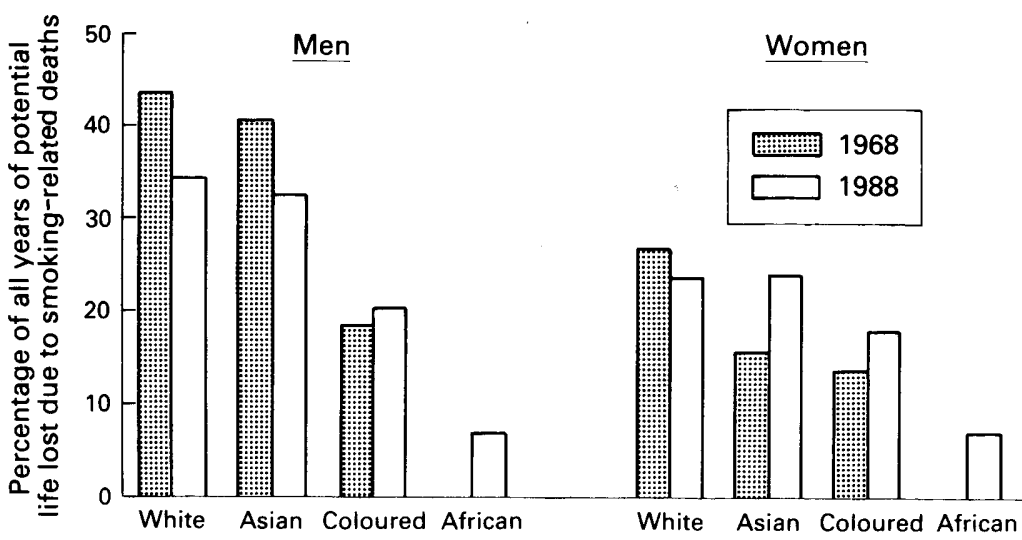

Figure 4 Percentage of all years of potential life lost (35-64 years) due to deaths from smoking-related diseases in South Africa by race and sex in 1968 and 1988

Table 4 Proportion of all deaths due to diseases related to smoking, South Africa, 1988, by race and sex

\begin{tabular}{|c|c|c|c|c|c|c|c|c|}
\hline & \multicolumn{2}{|c|}{ African } & \multicolumn{2}{|c|}{ White } & \multicolumn{2}{|c|}{ Coloured } & \multicolumn{2}{|c|}{ Asian } \\
\hline & Men & Women & Men & Women & Men & Women & Men & Women \\
\hline $\begin{array}{l}\text { Total deaths } \\
\% \text { Due to: }\end{array}$ & 70726 & 46403 & 21792 & 18156 & 15006 & 10930 & 3202 & 2162 \\
\hline Ischaemic heart disease & $0 \cdot 9$ & $0 \cdot 8$ & $23 \cdot 1$ & $17 \cdot 2$ & $6 \cdot 4$ & $6 \cdot 8$ & $19 \cdot 5$ & $14 \cdot 5$ \\
\hline Lung cancer & $1 \cdot 3$ & 0.5 & $4 \cdot 8$ & $2 \cdot 7$ & $4 \cdot 1$ & $1 \cdot 8$ & 1.6 & 0.7 \\
\hline Respiratory heart disease & $0 \cdot 8$ & $1 \cdot 0$ & $2 \cdot 2$ & $2 \cdot 6$ & 1.0 & $1 \cdot 2$ & 0.8 & $1 \cdot 1$ \\
\hline Chronic obstructive airways disease & $2 \cdot 7$ & $2 \cdot 3$ & 6.5 & $5 \cdot 6$ & $6 \cdot 4$ & $4 \cdot 6$ & $7 \cdot 3$ & $4 \cdot 3$ \\
\hline Aortic aneurysm & $0 \cdot 1$ & $0 \cdot 1$ & $1 \cdot 3$ & 0.6 & $0 \cdot 2$ & $0 \cdot 2$ & 0.1 & $0 \cdot 1$ \\
\hline Total & 5.8 & $4 \cdot 7$ & 37.9 & $28 \cdot 7$ & $18 \cdot 1$ & $14 \cdot 6$ & $29 \cdot 3$ & $20 \cdot 7$ \\
\hline
\end{tabular}

accounted for a total of 110856 potential years of life lost between 35 and 64 years of age in South Africans in 1988. This represented $30.7 \%$ of all potential years of life lost among white people (35-64 years), 30.0\% of all those lost among Asians, $19.4 \%$ of all of those lost among coloured people, and $6.9 \%$ of all of those lost among Africans.

\section{PASSIVE SMOKING AND DISEASE}

Though several international reviews have documented the impact of passive smoking on health, ${ }^{21,22}$ few studies have been completed in South Africa. One study investigating perinatal effects of maternal smoking showed that the newborn infants of smokers were $220 \mathrm{~g}$ lighter at birth than were those of nonsmokers. ${ }^{23}$ The effect on birth weight (a decline of between $90 \mathrm{~g}$ and $300 \mathrm{~g}$ among mothers who smoke) is particularly important in South Africa, where the proportion of babies with a low birth weight is already high and the risk of death in the first year of life still unacceptably high. In South Africa no intervention studies have been conducted to try to introduce cost effective methods of reducing the high proportion of babies with a low birth weight in the population.

\section{Economic impact of tobacco use} NOTES ON METHODS AND RESULTS

The methods of calculating the data presented in table 5 are detailed elsewhere. ${ }^{24}$ Lost productivity due to premature death is determined by calculating the net present value of earnings for smoking-related deaths in 1988 (based on the potential pre-retirement years of life lost according to age at death). Lost productivity estimates are adjusted for labour force participation and unemployment. In terms of health care costs, data were derived from the most recent hospital census. ${ }^{25}$

Based on these calculations, the total cost of smoking-related diseases, in terms of health care and lost productivity due to admission to hospital and premature mortality, was between 1390 million and 2453 million rands in 1988 ( $\$ 1=2.5$ rands).

The lower estimate is based on the assumption that only the people who are both available for employment and actually employed formally will experience a loss in productivity because of death from smokingrelated diseases. Conversely, the higher 
Table 5 Balance sheet of tobacco and health, South Africa (millions of rands), 1988

\begin{tabular}{lc|lc}
\multicolumn{1}{c|}{ Costs } & \multicolumn{2}{c}{ Benefits } \\
\hline Expenditure on tobacco & $2248 \cdot 0$ & Earnings of employees & $195 \cdot 2 \dagger$ \\
Lost productivity due to premature death & $1051 \cdot 0^{\star}$ & General Sales Tax on tobacco & $241 \cdot 0$ \\
Lost productivity due to hospital admission & $49 \cdot 5^{\star}$ & Excise revenue & $552 \cdot 0 \ddagger$ \\
Direct health care & $289 \cdot 6$ & Total & $988 \cdot 2$ \\
Total & $3638 \cdot 1$ & & \\
\hline
\end{tabular}

$\star$ Most conservative estimates.

Includes the employees in the manufacturing sector and farm workers (together they comprise $93 \%$ of total tobacco industry employees) and is based on average incomes in the case of farm workers. Data on tobacco industry and retailers profits are not readily available.

$\neq$ Data on employee and corporate tobacco tax are also not readily available.

estimate assumes that everyone would experience a loss in productivity. For example, a housewife, although not earning a monthly salary, would also incur productivity losses. This alternative assumption is particularly important in South Africa with its comparatively large informal sector.

A few points should be raised about the methods. Firstly, these calculations were based on the assumption that $25 \%$ of the deaths due to ischaemic heart disease and $85 \%$ of deaths due to lung cancer, chronic obstructive lung disease, respiratory heart disease, and aortic aneurysm are directly attributable to smoking. Secondly, the health care calculations are based on average estimates of inpatient and outpatient costs. There is an urgent need for detailed studies of the differential costs and attendances/admissions for the treatment of smoking-related diseases, which are likely to be higher than for other diseases. This is reflected in the latest tariff structure for Cape Provincial Administration whereby patients with cancer receiving medical aid are charged 410 rands per visit for chemotherapy ${ }^{26}$ (this is significantly higher than the average inpatient and outpatient day costs, which were 151 and 50 rands, respectively, in 1988). This should provide a reasonably accurate estimate of the associated costs as it was stated that the tariff scale would ensure that services would be rendered on a market-related basis. The health care costs must be regarded as an underestimate because of the chronic nature of smoking-related diseases.

Finally, many smoking-related costs were not included because of a lack of data. This includes productivity losses due to illness (absenteeism other than for hospital admission) and ill health (decreased output), private sector health care costs, increased insurance premiums for smokers, disability grants, health and other costs associated with passive smoking, and the cost of fires to property and forests. These costs should not be regarded as insignificant. For example, it has been found that cigarettes are the leading cause of household fires in the United States and account for roughly 2000 deaths from burns annually. ${ }^{27}$

OVERALL ESTIMATES: 1984 TO 1988

Given these caveats, the most conservative estimate of the economic impact of smokingrelated diseases in South Africa was 1.4 billion rands in 1988. Lost productivity due to premature mortality and hospital admission contributed $79 \%$ of these costs. It is important to note that direct public sector health care costs for treatment of diseases attributable to smoking increased by $125 \%$ between 1985 and 1988 - that is, an annual increase of about $42 \%$. This is partly because the average patient day cost nearly doubled during this period, but there was also an increase in days spent in hospital for smoking-related diseases $(34 \%$ increase in the case of white subjects, $12 \%$ in that of coloured people, $37 \%$ in that of Asians, and $4 \%$ in that of Africans).

\section{DIFFERENCES BETWEEN SOUTH AFRICA AND} DEVELOPED COUNTRIES

It has been noted that "At any given age, smokers incur greater health care costs than non-smokers. But precisely because smoking tends to kill smokers at an earlier age, nonsmokers have more years during which to incur health care bills. "27 Some studies have indicated that smoking-related health care costs may approximate those incurred by nonsmokers in old age. ${ }^{28}$ These findings are based on developed countries, but this will not necessarily be the case in South Africa, given its comparatively lower life expectancies. In addition, over $44 \%$ of the direct health care costs relate to white people, who use public sector facilities for many smoking-related health care services. These services are not provided by the private sector - for example, for the treatment of lung cancer. ${ }^{29}$ This will be exacerbated by the proposed changes to the Medical Schemes Act, which allows for "riskrating " - that is, in the future, it is more likely that health care costs of smokers will be borne by the state. It is thus a question of who bears the burden of health care costs - when considering the economic impact of smoking, one is primarily concerned with costs which are not incurred by smokers themselves.

\section{BENEFITS VERSUS COSTS}

Despite the gaps in current data, a balance sheet of tobacco and health can be derived for South Africa (table 5), as has been done in some international studies. ${ }^{30}$ From this summary it can be concluded that the economic costs of smoking to South Africa were significantly greater than the benefits in 1988 .

Prevention of smoking in South Africa

Several primary prevention strategies are being considered in South Africa. These include 
legislative and economic measures including controls on the unopposed impact of tobacco advertising; school-based programmes aimed at preventing smoking initiation among children; and community-based programmes aimed at encouraging adult smokers to stop.

ADVERTISING

In South Africa there are "voluntary agreements" between the industry and government which prohibit direct tobacco advertising on television and selected radio stations. However, the ubiquity of radio in South Africa ${ }^{31}$ allows the tobacco companies (despite a voluntary agreement) to reach their future new targets (rapidly urbanising African communities) fairly inexpensively through radio. Interestingly, an unnamed spokesperson for the tobacco industry stated that if there was a total ban on tobacco advertising, the tobacco industry would simply shift towards placing a greater emphasis on the direct marketing of tobacco products to consumers. He mentioned that RJ Reynolds has already established a database of 25 million smokers in the United States. ${ }^{32}$ In South Africa a recent Camel competition represents the start of local direct marketing. Participants interested in taking part in a four wheel drive rally were required to give their smoking status. Thus a mailing list is being assembled. ${ }^{33}$

Hardest hit by a total ban on tobacco advertising in South Africa would be screen advertisements in the cinema, where seven of the top 10 advertisers are tobacco brands, and billboards, where tobacco brands account for eight of the top 20 outdoor advertisers. A total ban on tobacco advertising is supported locally by the Medical Association of South Africa, the Epidemiological Society of Southern Africa, and the Council Against Smoking.

Partial curbs on tobacco advertising in South Africa will probably be enacted legislatively in 1992. The emphasis will be on rotating health warnings on all adverts.

\section{TAXATION POLICIES}

Though estimates of the price elasticity of cigarettes - that is, how responsive demand is to price changes - vary between countries ${ }^{28.34}$ and as a result of methodological differences, there seems to be a growing consensus in developed countries that the price elasticity is approximately $-0.5^{36}$ - that is, a $10 \%$ increase in price will result in a $5 \%$ decrease in sales. $^{35-37}$

Figure 5 highlights the trend in prices and tobacco taxation in South Africa since 1980. All data have been indexed to 1980 figures so that the relative changes can be clearly identified. The retail price of cigarettes has lagged behind the overall consumer price index over the past decade - that is, the real price of cigarettes has fallen. Given current estimates of the price elasticity of tobacco products, this suggests that the $17 \%$ drop in real cigarette prices between 1980 and 1988 would in effect have encouraged at least a $8.5 \%$ increase in

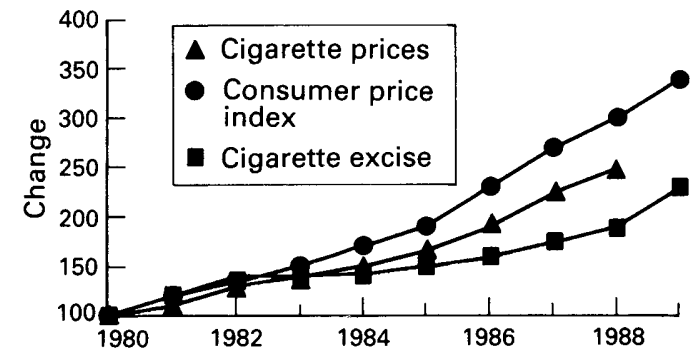

Figure 5 Changes in cigarette prices and excise revenue relative to consumer price index

Table 6 Tobacco tax as a percentage of total central government tax revenue ${ }^{\star}$

\begin{tabular}{lr}
\hline Zaire & $26 \cdot 3$ \\
Tanzania & $16 \cdot 3$ \\
Malawi & $16 \cdot 7$ \\
Kenya & $9 \cdot 3$ \\
Nigeria & $7 \cdot 6$ \\
Tunisia & $6 \cdot 3$ \\
Egypt & $5 \cdot 7$ \\
Zimbabwe & $4 \cdot 6$ \\
Ethiopia & $4 \cdot 3$ \\
South Africa & $1 \cdot 7$ \\
Algeria & $0 \cdot 2$ \\
\hline
\end{tabular}

* Chapman and Wai Leng $1990 .^{30}$

consumption. Furthermore, total excise tax revenue from cigarettes and cigarette tobacco has not kept pace with inflation; there has been a $50 \%$ decrease in real tobacco excise tax revenue over this period. Importantly, table 6 indicates that South Africa obtains among the lowest proportion of total central government tax revenue from tobacco taxation compared with other African countries. Ensuring that tax increases are at least equivalent to consumer price increases will go some way towards preventing further expansion of tobacco markets.

A final argument in favour of a high taxation policy is the finding that there is a higher price elasticity for teenage smokers as they have fewer resources for tobacco expenditure and are less likely to be heavily addicted. Data presented earlier indicate that smoking rates in the 16-24 year age group are substantial and given that demand in this group is particularly responsive to price changes, this policy is even more justifiable. The result would be to severely restrict new young entrants to the tobacco market, which would reduce adverse health consequences because the relative risk of smoking-related diseases is likely to be less for young ex-smokers than for older exsmokers, given their shorter smoking history.

\section{SCHOOL-BASED PROGRAMMES}

Special attention in South Africa is needed to provide long term support for programmes based at schools, which start countering the unopposed effect of tobacco advertising. Furthermore, the reality that a high proportion of school age children are not in school and are likely to be among the highest tobacco users both internationally ${ }^{38}$ and in South Africa means that special programmes are required to reach this high risk adolescent group through community outreach programmes. Clearly an emphasis on the school aged population who 
do not attend school would not only emphasise tobacco prevention, but as importantly, all other aspects of substance abuse, violence, and unsafe sex.

As adolescence is a period of smoking experimentation and initiation, particular emphasis in school-based programmes on refusal skills has proved to be useful in the United States $^{39}$ and in limited studies in South Africa. ${ }^{40}$ A school-based prevention programme was carried out between September and November 1989 when an anti-tobacco health promotion programme was tested in two black townships in Cape Town. ${ }^{40}$ The programme used training concepts derived from social cognitive theory to promote self confidence in pupils' ability to perform health enhancing behaviour. The programme was taught in the vernacular using a specially prepared teachers' manual. Early indications are that there were no new cigarette smokers in the intervention school; there was an increase in self confidence of the pupils; teachers and parents received the programme enthusiastically; and the programme was strongly supported by the school curricular boards. Even though long term evaluations were not carried out, this preliminary study is likely to be a model for innovative school-based tobacco and health programmes.

As part of creating an environment in which it is difficult for children to start smoking, a ban on the sale of tobacco products to children backed by an aggressive multimedia campaign, has been shown to be effective in the United States. ${ }^{41}$ Similar strategies will be required when legislation is introduced in 1992 to ban cigarette sales to children in South Africa. The legislation alone will not be sufficient unless it is accompanied by such an aggressive media campaign and is enforced.

\section{COMMUNITY INTERVENTIONS}

In South Africa a prospective anti-smoking trial was conducted as part of the coronary risk factor intervention study in three rural communities in the south western Cape over a period of four years. ${ }^{15}$ The effect was evaluated by examining the net change in smoking prevalence, which was defined as the residual change in the intervention areas after allowing for change in the reference area. The intervention programme among men in the high intensity intervention area resulted in a reduction of $8.4 \%$ in smoking prevalence and $13.0 \%$ in the amount smoked per day. Among women in this area there was a reduction of $13.6 \%$ in smoking prevalence and $20.5 \%$ in the amount smoked. Rates of stopping smoking were strongly associated with initial smoking levels, with light smokers (fewer than 10 cigarettes per day) being significantly more successful quitters than were heavy smokers ( 20 or more cigarettes per day). The study shows that a community-based intervention programme can effectively reduce smoking and is likely to be extended to other community-based groups in South Africa.

It is particularly in the workplace that such quitting programmes have been evaluated and found to be effective. ${ }^{42}$ Industries in the western Cape region of South Africa indicated an increased interest and request for help in the design of appropriate programmes to prevent smoking in the workplace. ${ }^{43}$ During the late 1980s and in 1990-1 several South African companies - for example, ParkeDavis, a division of Warner Lambert - and organisations such as the Medical Research Council actively publicised the fact that smoking is banned in their workplace. This is likely to have a ripple effect over time. Unfortunately, however, the major unions in the country have yet to take up tobacco and health as a major concern.

\section{Non-governmental organisations active against tobacco use}

In May 1991 the three principal voluntary organisations with an interest in controlling smoking - the Council Against Smoking, the National Cancer Association, and the Heart Foundation of South Africa-formed a coalition, the Tobacco Action Group, to coordinate their anti-smoking activities.

These pressure groups have in the past made some progress by supplying information to the public, doctors, schools, media, and politicians. Some of the changes they have helped to promote include a ban on smoking on all internal flights on South African Airways; statement of the tar and nicotine yields of cigarettes on the packaging; and the passing of a bylaw in September 1991 by the Johannesburg City Council requiring restaurants with more than 50 seats to allocate $60 \%$ of their tables to non-smokers. More importantly, public attitudes are changing. In a national survey completed in March 1992 the majority of people in both rural and urban areas are now aware that smoking is a health hazard (G Martin, personal communication, 1992).

The Tobacco Action Group plans to launch a major campaign in 1992 to try to ensure the successful passage through parliament of the draft bill providing for the control and regulation of the use and advertising of tobacco products. The draft legislation gives the health minister powers to bar or limit (a) smoking in public places and $(b)$ the advertising of tobacco. It also bans the sale of cigarettes to minors. Current indications are that the minister intends to tighten controls on advertising but will stop short of an outright ban. The Tobacco Action Group, however, wants the government to move to a comprehensive anti-smoking strategy that includes increased taxation of tobacco products, a total ban on tobacco advertising, a ban on sales of tobacco products to children, restrictions on smoking in public places, and mandatory health education in schools.

\section{Conclusion}

Overall analysis of the mortality data indicates that gains being made with respect to preventable infectious diseases are giving way to 
considerable new health costs being introduced by having to treat conditions requiring costly care such as ischaemic heart disease and lung cancer. South Africa is therefore not experiencing an "epidemiological transition" but rather an "epidemiological trap" in which it has the worst of both worlds - that is, the infectious diseases of the past and high rates of chronic diseases (predominantly induced by lifestyles associated with tobacco, alcohol, and trauma) as well as the new and future impact of HIV and AIDS.

The current challenge for public health professionals is to ensure that as political change unfolds tobacco company exploitation of rapidly urbanising populations is opposed.

Financial support from Ciba-Geigy (Pty) Ltd and the Medical Research Council is gratefully acknowledged. The views represented here are those of the authors and not necessarily their organisations.

1 Yach D. The impact of smoking in developing countries with special reference to Africa. Int $\mathcal{f}$ Health Serv 1986 16: 279-92.

2 Kiernan VG. Tobacco: a history. London: Hutchinson Radius, 1991.

3 Quality above all. The story of Rembrandt. Stellenbosch: Rembrandt Tobacco Manufacturing Corporation of South Africa Limited, 1978

4 Muller M. Tobacco in the third world: tomorrow's epidemic. London: War on Want, 1978

5 Mackay J. Tobacco and the Third World. Thorax 1991; 46 153-6.

6 Peto R, Lopez AD and the WHO Consultative Group on Statistical Aspects of Tobacco-Related Mortality. Worldwide mortality from current smoking patterns. In: Durston B, Jamrozik K, eds. Tobacco and health 1990 the global war. Perth: Health Department of Wester Australia, 1990: 66-8. (Proceedings of the seventh world conference on tobacco and health.)

7 Benatar SR. Medicine and health care in South Africa - five years later. $N$ Engl f Med 1991; 325: 30-6.

8 Botha JL, Bradshaw D, Gonin R, Yach D. The distribution of health needs and services in South Africa. Soc Sci Med $1988 ; 26: 845-51$.

9 Medical Research Council and Henry J Kaiser Family Foundation. Changing health in South Africa: towards new perspectives in research. California: Henry J Kaise Family Foundation, 1991

10 Yach D, Townshend G. Smoking and health in South Africa : the need for action. Parow: South African Medical Research Council, 1988. Centre for Epidemiological Research in Southern Africa, Technical Report No 1.)

11 Steenkamp E, Jooste PL, Christopher KG. The prevalence of smoking and its relationship to other coronary risk factors in a rural white community. S Afr Med $\mathcal{F} 1988$; 73: $302-5$.

12 Steyn K, Jooste PL, Langenhoven M, Roussouw JE, Steyn $M$, Jordaan PCJ, et al. Smoking patterns in the coloured population of the Cape Peninsula (CRISIC study). $S$ Afr population of the Cape $1987 ; 71: 145-8$.

13 Steyn K, Jooste PL, Bourne L, Fourie J, Badenhorst CJ Bourne DE, et al. Risk factors for coronary heart disease in the black population of the Cape Peninsula. Th BRISK study. $S$ Afr Med f 1991 ; 79: 480-5.

14 Seedat YK, Mayet FGH, Kahn S, Somers SR, Joubert G. Risk factors for coronary heart disease in the Indians of Durban. S Afr Med $\mathcal{f} 1990 ; 78: 447-54$

15 Steenkamp HJ, Jooste PL, Jordaan PCJ, Swanepoel ASP, Roussouw JE. Changes in smoking during a community based cardiovascular disease intervention programme.
The coronary risk factor study. S Afr Med f 1991; 79 250-3.

16 Strebel P, Kuhn L, Yach D. Smoking practices in the Black township population of Cape Town. S Afr Med $\mathcal{F} 1989$ 75: 428-31.

17 Strebel P, Kuhn L, Yach D. Determinants of cigarette smoking in the black township population of Cape Town. f Epidemiol Community Health 1989; 43: 209-13.

18 Yach D. Infant mortality rates in urban areas of South Africa (1981-1985). S Afr Med F 1988; 73: 232-4.

19 World Health Organisation-International Agency on Cancer. IARC monographs on the evaluation of the carcinogenic risk of chemicals to humans: tobacco smoking. Vol 38. Lyons: IARC, 1986.

20 Sasco A, World burden of tobacco-related cancer. Lancet $1991 ; 338: 123-4$

21 US Department of Health and Human Services. Environmental tobacco smoke in the workplace: lung cancer and other health effects. Atlanta: Centers for Disease Control, National Institute for Occupational Safety and Health, 1991. (NIOSH Current Intelligence Bulletin 54. )

22 Spitzer WO, Lawrence B, Dales R, Hill G, Archer MC Clark $\mathrm{P}$, et al. Links between passive smoking and disease: a best evidence synthesis. A report of the Working Group on Passive Smoking. Clin Invest Med 1990; 13: 17-42.

23 Rothberg AD, Shisenyane E, Lits B, Strebel PM. Medical and/or obstetric problems and birth weight in two Johannesburg populations. South African fournal of Epidemiology and Infection 1990; 5(2): 37-9.

24 McIntyre DE, Taylor SP. Economic aspects of smoking in South Africa. S Afr Med F 1989; 75: 432-5.

25 Central Statistical Services. Census of hospitals, clinics and other health service establishments, 1987 . Pretoria: Central other health service establishments, 1987. Pretoria:
Statistical Service, 1989. (Report No 93-01-01.)

26 Cape Times 1991 Apr 9.

27 Warner KE. Health and economic implications of a tobaccofree society. $\mathcal{F} A M A$ 1987; 258: 2080-6.

28 Leu RE. Economic aspects of smoking. Geneva: World Health Organisation, 1982. (WHO Expert Committee on Smoking Control Strategies in Developing Countries.)

29 McIntyre DE, Dorrington RE. Trends in the distribution of South African health care expenditure. $S$ Afr Med $\mathcal{Y}$ 1990; 78: 125-9.

30 Chapman S, Wai Leng W. Tobacco control in the Third World: a resource atlas. Penang: International Organisation of Consumers Unions, 1990.

31 Green M, Lascaris R. Communication in the Third World: seizing advertising opportunities in the 1990s. Cape Town: Tafelberg Human and Rossouw, 1990.

32 Weekend Argus 1991 July 6: 5 .

33 Yach D. Direct marketing of tobacco products. $S$ Afr Med f 1991;80:517.

34 Pekurinen $M$, Valtonen $H$. Price, policy and consumption of tobacco: the Finnish experience. Soc Sci Med 1987; 25 : 875-81.

35 Godfrey C, Maynard A. Economic aspects of tobacco use and taxation policy. BMF $1988 ; 297: 339-43$.

36 Peterson DE, Zeger SL, Remington PL, Anderson HA. The effect of State cigarette tax increases on cigarette sales: 1955-1988. Am F Public Health 1992; 82: 94-6.

37 Chapman S, Richardson J. Tobacco excise and declining tobacco consumption: the case of Papua New Guinea. Am F Public Health 1990; 80: 537-9.

38 Glynn TJ, Anderson DM, Schwarz L. Tobacco use reduction among high-risk youth: recommendations of the National Cancer Expert Advisory Panel. Prev Med 1991; 20: 279-91.

39 Katz RC, Robisch CM, Telch MJ. Acquisition of smoking refusal skills in junior high school students. Addict Behav $1989 ; 14: 201-4$

40 Hunter S MacD, Steyn K, Yach D, Sipamla N. Selfconfidence enhancement: a new anti-tobacco approach in
South Africa. Am $\mathcal{J}$ Public Health 1991; 8: 928-9.

41 Altman DG, Foster V, Rasenick-Douss L, Tye JB Reducing the illegal sale of cigarettes to minors. $\mathcal{F} A M A$ $1989 ; 261: 80-3$.

42 Shipley RH, Orleans CT, Wilbur CS, Piserchia PV, McFaden DW. Effect of the Johnson and Johnson Live for Life programme on employee smoking. Prev Med $1988 ; 17: 25-34$.

43 Metcalf CA, Yach D. Smoking policies in the workplace in the Western Cape. S Afr Med $\mathcal{f} 1992 ; 81: 23-6$. 


\section{Translations Le tabagisme en Afrique du Sud: of abstract}

\section{Tabaquismo en Sudáfrica: las repercusiones para la salud y las económicas}

Derek Yach et al

\section{Résumé}

Objectifs: Décrire les impacts sanitaires et économiques du tabagisme en Afrique de Sud et signaler les mesures actuelles de prévention.

Méthodologie: Statistiques de mortalité, informations fournies par les hôpitaux, données relatives à la consommation en provenance des secteurs publics et privés.

Résultats: En 1988, en Afrique du Sud, les pourcentages de décès dus au tabagisme représentaient respectivement: pour la population blanche $33,7 \%$, pour la population asiatique $25 \%$, pour la populaion métisse $16,6 \%$, pour la population noire $5,4 \%$.

Le pourcentage total des années de vie perdues 35 à 64 ans) en raison de tabagisme diminuait pour la période comprise entre 1968 et 1988 dans la population masculine blanche et asiatique mais augmentait dans les autres groupes.

En 1989/90, le pourcentage global de fumeurs chez les plus de 16 ans était de $31 \%$.

Le nombre de fumeurs dans la population masculine noire et métisse était particulièrement élevé. Il y avait très peu de fumeuses chez les femmes noires et asiatiques. Dans tous les cas, les taux les plus se trouvaient chez les personnes ayant reçu une éducation universitaire.

En appliquant les pourcentages de 1976 à la population de 1990 on obtenait 320.000 fumeurs supplémentaires dans la population noire, 80.000 fumeurs supplémantaires dans la population métisse, 40.000 dans la population asiatique et 270.000 dans la population blanche. Ces augmentations sont liées à la stratégie de promotion agressive des fabricants de tabac, qui cible sans aucune opposition les groupes sensibles. La publicité utilise le cinéma, les panneaux d'affichage et la radio. Le coût économique global des maladies liées au tabagisme était évalué, en 1988, entre 1.390 et 2.453 milliards de rands ( 1 dollar vaut environ 2,5 rands).

Conclusion: Alors que les changements politiques et sociaux continuent de se produire en Afrique du Sud, des programmes globaux de prévention du tabagisme sont nécessaires pour éviter que les progrès acquis dans la réduction des maladies infectieuses soient éclipsés par les coûts croissants des maladies liées au tabagisme.

\section{Resumen}

Objetivo: Describir las repercusiones para la salud y las económicas del tabaquismo en Sudáfrica y señalar las actividades de prevención actuales.

Métodos: Se recopilaron y analizaron las estadísticas de mortalidad, los datos disponibles de egresos de hospitales y los datos de prevalencia de los sectores público y privado de ordinario.

Resultados: En 1988, las enfermedades relacionadas con el tabaquismo en Sudáfrica representaron 33,7\% de las defunciones entre los blancos, $25,8 \%$ entre los asiáticos, $16,6 \%$ entre los mestizos y $5,4 \%$ entre los africanos. El porcentaje de los años potenciales de vida perdidos (entre 35 y 64 años) debido a las defunciones relacionadas con el tabaquismo entre 1968 y 1988 descendió entre los hombres blancos y los asiáticos, pero aumentó en los otros grupos.

La tasa general de tabaquismo en $1989-90$ en las personas de más de 16 años de edad fue de $31 \%$. Las tasas de tabaquismo entre los hombres africanos y mestizos fueron particularmente altas; las tasas entre las mujeres africanas y las asiáticas fueron particularmente bajas; las tasas para todas las razas fueron las más bajas entre las personas con educación universitaria. Cuando las tasas de tabaquismo de 1976 se aplicaron a la población de 1990 , se calcularon 320000 fumadores africanos más, 80000 fumadores mestizos más, 40000 fumadores asiáticos más y 270000 fumadores blancos menos. Los aumentos se relacionaron con los efectos no contrarrestados de las intensivas campañas de comercialización de las empresas tabacaleras entre los grupos susceptibles. Los anunciantes concentraron su atención en los cines, las carteleras y las radio. Se estimó que el costo económico total de las enfermedades relacionadas con el tabaquismo era entre 1,39 billones y 2,453 billones de rands en 1988 ( 1 dólar de los Estados Unidos equivale aproximadamente a 2,5 rands).

Conclusión: A medida que Sudáfrica experimente mayores cambios sociopolíticos, se necesitarán programas integrales de prevención del tabaquismo para lograr que el terreno ganado en la reducción de las enfermedades infecciosas no se pierda a causa de los costos derivados del aumento de las enfermedades relacionadas con el tabaquismo.

\section{在南非吸烟对健康和经济的影响 德利克・亚奇等}

研究目的：阐述在南非烟草对健康和经济的影响, 并列举现行的控制吸烟活动。

研究方法：对常规收集的、可资利用的死亡统计资料、医院出院证明和私立.或公立机构调查 获得的吸烟率资料进行了收集和分析。

研究结果: 1988 年在南非, 与吸烟有关疾病的死亡中, 白人占 $33.7 \%$; 亚裔人占 $25.8 \%$, 有色 人种占 $16.6 \%$, 非洲人占 $5.4 \%$ 。在白人和亚裔人的男性中，归因于与吸烟有关疾病的寿命损 失占总寿命损失的百分比在 1968 年至 1988 年期间呈下降趋势, 但其它人群中相应的百分比 则呈上升趋势。1989-90 年 16 岁以上成人的总吸烟率是 $31 \%$ 。非洲人和有色人种的男性吸 烟率特别高，而非洲和亚洲的女性吸烟率则特别低。在所有种族中，受过高等教育人的吸烟 率是最低的。将 1976 年吸烟率的调查结果与 1990 年基础人口资料结合进行分析时，可以推 断，非洲人、有色人种和亚裔人的吸烟者分别增加了. 320,000 人、 80,000 人和 40,000 人，而 白人吸烟人数则下降了 270,000 人。吸烟者的增加是由于烟草公司在易患人群中强有力的市 场销售的联合影响。烟草广告商的目标主要是在影剧院、街头广告牌和广播。1988 年与吸烟 有关疾病总的经济损失与吸烟有关疾病总的经济花费估计在 $13.90 \sim 24.53$ 亿兰特之间（1 美 元 $=2.5$ 兰特)。

结论：在南非正经历着进一步社会政治变革的同时，必须开展广泛而深人的反吸烟运动，以 确保从降低传染性疾病中获得的收益不会因与吸烟有关疾病花费的增加而付之东流。 